\title{
Corrigendum
}

\section{Late Pleistocene and Early Holocene aeolian deposits of Tasmania and their climatic implications - Corrigendum}

\author{
Peter D. McIntosh, Christina Neudorf, Olav B. Lian, Adrian J. Slee, Brianna Walker, Rolan Eberhard, Richard Doyle \\ and Grant Dixon
}

Published online by Cambridge University Press 13 November 2020; doi: https://doi.org/10.1017/qua.2020.83

In the original publication of McIntosh et al. (2020), calibrated ${ }^{14} \mathrm{C}$ ages in Table 1 were calculated from the OxCal IntCal13 curve. They should have been calculated from the Oxcal SHCal20 (southern hemisphere) curve (Hogg et al. 2020). Correct calibrated ages are shown in the fourth column of the table below. When quoting ${ }^{14} \mathrm{C}$ ages from Table 1 or from the text of McIntosh et al. (2020) the values in column 4 of the table below should be used. The correction of calibrated ${ }^{14} \mathrm{C}$ ages is minor and does not affect the interpretations and conclusions of McIntosh et al. (2020).

\section{REFERENCES}

Hogg, A., Heaton, T., Hua, Q., Palmer, J., Turney, C., Southon, J., Bayliss, A., Blackwell, P., Boswijk, G., Bronk Ramsey, C., Petchey, F., Reimer, P., Reimer, R. and Wacker, L. 2020. SHCal20 Southern Hemisphere calibration, 0-55,000 years cal BP. Radiocarbon 62.

McIntosh, P. D., Neudorf, C., Lian, O. B., Slee, A. J., Walker, B., Eberhard, R., Doyle, R., et al. Late Pleistocene and Early Holocene aeolian deposits of Tasmania and their climatic implications. Quaternary Research, first published online 13 November 2020; https://doi.org/10.1017/qua.2020.83 


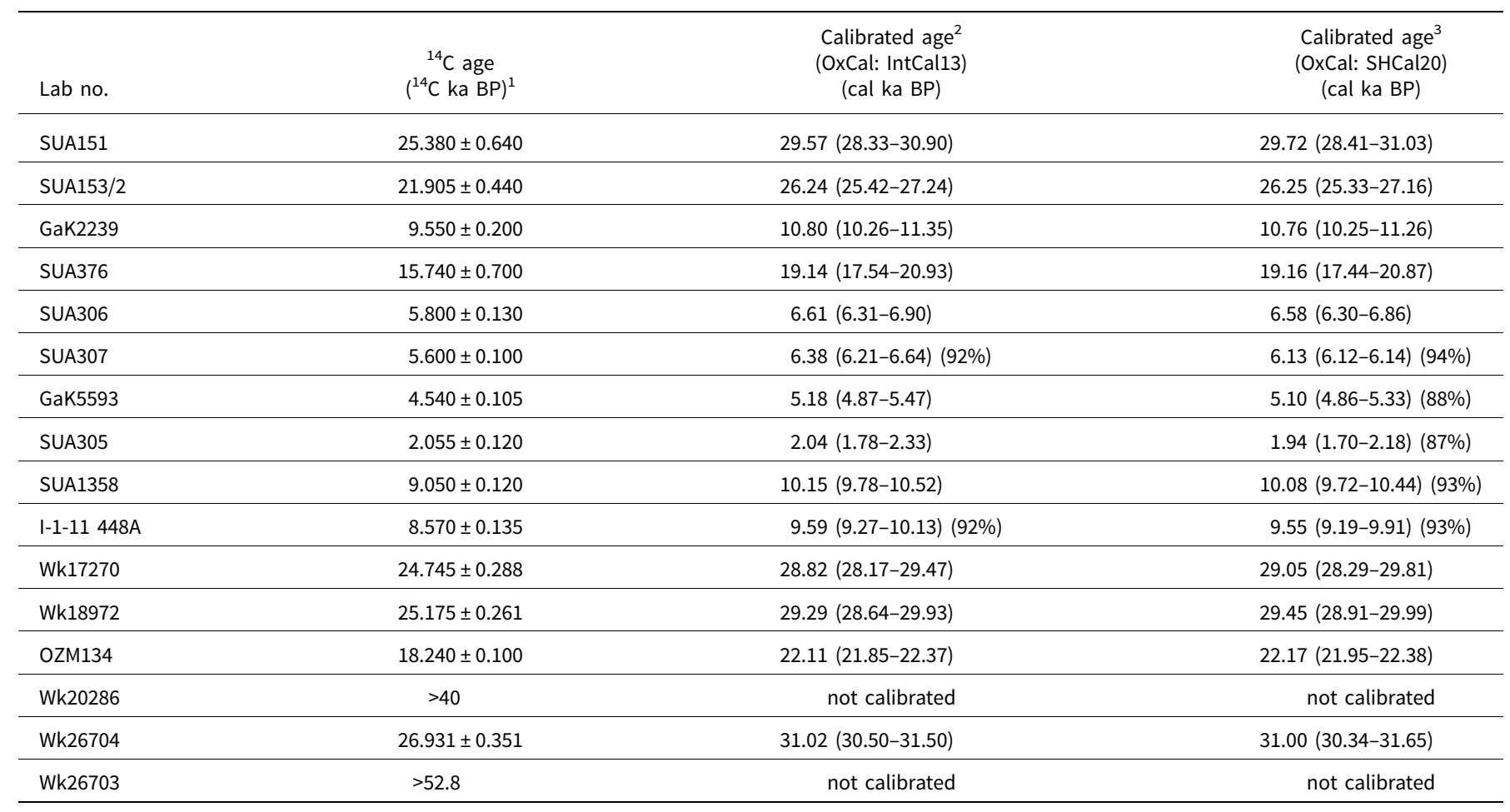

${ }^{1}$ Laboratory values as reported (not rounded).

${ }^{2}$ Median ages (rounded to two decimal places), with 95\% probability ranges in parenthesis, except where indicated; based on IntCal13 and as reported in Mclntosh et al. (2020, Table 1 ).

${ }^{3}$ Corrected median ages (rounded to two decimal places), with 95\% probability ranges in parenthesis, except where indicated; based on SHCal20 (Hogg et al. 2020). 